DOI: https://doi.org/10.24127/ajpm.v10i3.3969

\title{
PENGARUH MODEL PROBLEM BASED LEARNING BERBANTUAN APLIKASI GAGUNG DURAN TERHADAP KEMAMPUAN PEMECAHAN MASALAH SISWA
}

\author{
Royyana Ulyl Albab ${ }^{1 *}$, Savitri Wanabuliandari ${ }^{2}$, Sumaji $^{3}$ \\ ${ }^{1 * 2,3}$ Universitas Muria Kudus, Kudus, Indonesia \\ *Corresponding author. Gondangmanis, Bae,59352, Kudus, Indonesia. \\ E-mail: $\quad \underline{201735022 @ u m k . a c . i d}^{\left.1^{*}\right)}$ \\ savitriwanabuliandari@umk.ac.id ${ }^{2)}$ \\ sumaji@umk.ac.id $^{3 *}$
}

Received 12 July 2021; Received in revised form 13 September 2021; Accepted 29 September 2021

\begin{abstract}
Abstrak
Tujuan dari penelitian ini yaitu: (1) Untuk menganalisis perbedaan rata-rata kemampuan pemecahan masalah siswa yang memperoleh pembelajaran model Problem Based Learning berbantuan aplikasi Gagung Duran dibandingkan siswa yang memperoleh pembelajaran secara konvensional; (2) Untuk menguji apakah rata-rata kemampuan pemecahan masalah siswa sesudah diterapkan model Problem Based Learning berbantuan aplikasi Gagung Duran lebih baik daripada sebelumnya. Metode penelitian yang digunakan adalah kuantitatif dan desain yang digunakan dalam penelitian ini adalah tipe eksperimen sejati. Desain dalam penelitian adalah randomized pre-test and post-test design. Populasi dalam penelitian ini adalah siswa SMP 1 Mejobo kelas VIII dimana pemilihan sample menggunakan metode cluster sampling. Data diperoleh dari hasil tes kemampuan pemecahan masalah. Analisis data pada rumus pertama menggunakan uji prasyarat dan uji t untuk sampel independen, dan rumus kedua menggunakan uji prasyarat dan uji t untuk pasangan sampel. Hasil penelitian membuktikan bahwa dengan menggunakan model Problem Based Learning berbantuan aplikasi Gagung Duran dapat menjadikan siswa lebih mandiri dalam proses belajar serta siswa bisa memahami materi secara mendalam dengan cara melatih menyelesaikan masalah terkait dengan keseharian siswa. Dengan penelitian ini disimpulkan bahwa: (1) Terdapat perbedaan rata-rata kemampuan pemecahan masalah kelas eksperimen dibandingkan kelas kontrol; (2) Rata-rata kemampuan pemecahan masalah siswa sebelum perlakuan lebih rendah dibandingkan sesudah diterapkan perlakuan.
\end{abstract}

Kata kunci: Aplikasi gagung duran; kemampuan pemecahan masalah; problem based learning.

\begin{abstract}
The aims of this study are: (1) To analyze the difference in the average problem-solving abilities of students who received Problem Based Learning models assisted by the Gagung Duran application compared to students who received conventional learning; (2) To test whether the average problem solving ability of students after the application of the Problem Based Learning model assisted by the Gagung Duran application is better than before. The research method used is quantitative, the design used in this study is a true experimental type. While the design chosen by the researcher is the randomizes pretest-posttest design. The population in this study were students of SMP I Mejobo class VIII using the Cluster Sampling approach. The data were obtained from the results of the problem-solving ability test. Data analysis in the first formulation used a prerequisite test and independent sample t test, the second formulation used a prerequisite test and paired sample test. The results of the study prove that using the Problem Based Learning model with the help of the Gagung Duran application can improve students' problem solving abilities than before the treatment was applied. And can increase the average ability of students compared to students who get conventional learning. In this study, it was found that: (1) There was a difference in the average problem-solving ability of the experimental class compared to the control class; (2) The average problem solving ability of students before the treatment was lower than after the treatment was applied. For further research, it is possible that the implementation of learning can be adjusted to the ability of students and the achievement of the learning to be carried out.
\end{abstract}

Keywords: Gagung duran app's; problem based learning; problem solving.

This is an open access article under the Creative Commons Attribution 4.0 International License 
DOI: https://doi.org/10.24127/ajpm.v10i3.3969

\section{PENDAHULUAN}

Pada era teknologi saat ini, penggunaan media berbasis teknologi sangat dibutuhkan untuk meningkatkan pola pikir siswa. Dimana siswa lebih banyak belajar secara mandiri pada masa pandemi. Sehingga tidak memungkiri siswa menjadi kesulitan dalam belajarnya. Maka dari itu diperlukanya model ataupun media pembelajaran inovatif yang dapat meningkatkan kecerdasan anak. Salah satunya adalah dalam bidang kemampuan pemecaha masalah siswa. Dimana kemampuan pemecahan masalah ini takluput dari kehidupan sehari-hari. Oleh sebab itu kemampuan pemecahan masalah siswa itu penting untuk dikembangkan oleh anak.

Terdapat beberapa faktor yang mempengaruhi kemampuan pemecahan masalah siswa. Diantaranya siswa belum terbiasa untuk menyelesaikan soal-soal non rutin (Afriansyah, 2016; (Putri, Suryani, \& Jufri, 2019). Sejalan dengan pendapat tersebut, diperoleh $80 \%$ siswa masih kesulitan dalam mengerjakan soal kemampuan pemecahan masalah siswa (Fasha, Johar, \& Ikhsan, 2018). Pemecahan masalah merupakan salah satu bagian terpenting dari kurikulum 2013 itu sendiri, maka dari itu pemecahan masalah merupakan hal yang penting untuk meningkatkan pola bepikir siswa. Pada masa pandemi ini bahwa $82,25 \%$ siswa mengalami memahami kesulitan dalam pelajaran matematika melalui pembelajaran daring di beberapa sekolah (Kharisma, Roesminingsih, \& Suhanadji, 2020). Hal tersebut dibuktikan dengan hasil tes studi banding kemampuan pemecahan masalah siswa mencapai $63 \%$.

Maka dari itu, diperlukannya model atau media pembelajaran digital yang dapat meningkatkan kemampuan pemecahan masalah siswa. Berdasarkan penelitian yang relevan menurut (Puadi \& Habibie, 2018) dengan mengunakan media aplikasi dapat memudahkan siswa untuk memahami dan mengikuti pembelajaran dengan baik. Pembelajaran berbasis masalah juga dapat mempengaruhi kemampuan pemecahan masalah pada siswa.

Pembelajaran berbasis masalah atau disebut juga problem based learning (PBL) merupakan pembelajaran dalam upaya meningkatkan kemampuan pemecahan masalah (Cahyani \& Setyawati, 2016). Menurut (Barrow, 2913; (Abdurrozak, Jayadinata, \& 'Atun, 2016)) PBL adalah proses dalam memahami atau resolusi masalah diperoleh dari pembelajaran. Selain itu menurut (Sujana, 2014; (Abdurrozak, Jayadinata, \& 'Atun, 2016) PBL merupakan proses pembelajaran yang menyajikan permasalahan secara nyata, sehingga dalam mengatasi masalah dapat dijadikan acuan untuk melaksanakan investigasi dan penelitian.

Kelebihan model PBL menurut (Shoimin, 2016; (Rerung, Sinon, \& Widayaningsih, 2017) antara lain: 1) siswa diajarkan untuk memiliki kemampuan memecahkan masalah dalam kehidupan nyata; 2) memiliki kemampuan dalam mengem-bangkan pengetahuannya sendiri; 3) pembelajaran terfokus pada masalah. Untuk mengurangi beban siswa dalam menghafal atau menyimpan informasi; 4) menjadikan siswa lebih aktif dalam kerja kelompok; 5) membiasakan siswa menggunakan sumber belajar lain selain guru, baik dari perpustakaan, internet, wawancara, dan observasi; 6) meningkatkan minat siswa untuk belajar mandiri; 7) meningkatkan softskill siswa dalam berdiskusi atau dalam mempresentasikan hasil dari pekerjaan mereka; dan 8) kesulitan siswa dalam belajar dapat diatasi dengan kerja kelompok. 
DOI: https://doi.org/10.24127/ajpm.v10i3.3969

Upaya untuk memperkuat kemampuan pemecahan masalahan siswa terutama dalam materi garis singgung dua lingkaran maka dibuatlah media pembelajaran berbasis android yang bernama Gagung Duran. Aplikasi Gagung Duran merupakan kependekan dari garis siggung dua lingkaran dimana modul atau materi pembelajaran garis singgung dua lingkaran dimasukkan ke dalam sebuah aplikasi dimana siswa bisa menggunakannya secara interaktif. Sehingga dengan aplikasi Gagung Duran peserta didik dapat belajar melalui aplikasi tersebut seutuhnya dan bisa melakukan pembelajaran yang interaktif karena siswa dapat menggunakannya secara mandiri untuk dipelajari. Dengan demikian, harapan dalam pembelajaran menggunakan model Problem Based Learning berbantuan aplikasi Gagung Duran ini dapat memberikan kemudahan bagi siswa dalam memecahkan masalah yang berkaitan dengan materi garis singgung dua lingkaran, dan juga memberikan wawasan kepada siswa tahap-tahap dalam memecahkan masalah.

Tujuan dari penelitian ini yaitu: (1) Untuk menganalisis perbedaan ratarata kemampuan pemecahan masalah siswa yang memperoleh pembelajaran model Problem Based Learning berbantuan aplikasi Gagung Duran dibandingkan siswa yang memperoleh pembelajaran secara konvensional; (2) Untuk menguji apakah rata-rata kemampuan pemecahan masalah siswa sesudah diterapkan model Problem Based Learning berbantuan aplikasi Gagung Duran lebih baik daripada sebelumnya.

\section{METODE PENELITIAN}

Penelitian dilaksanakan di SMP 1 Mejobo. Pendekatan penelitian yang digunakan dalam penelitain ini adalah kuantitatif. Desain yang digunakan dalam penelitian ini adalah jenis true experimental. (Sugiyono, 2015) mengungkapkan True experimental merupakan penelitian yang dilakukan dengan menggunakan dua kelompok, dimana satu kelas yang diberi perilaku sebagai kelas eksperimental dan kelas lainya tanpa perlakuan sebagai kelas kontrol. Sedangkan rancangan yang dipilih adalah therandomizes pretestpostest design. Adapun rancangan penelitian ini dapat dilihat pada Gambar 1.

\begin{tabular}{|lll|}
\hline $\mathrm{O} 1$ & $\mathrm{X}$ & $\mathrm{O} 2$ \\
$\mathrm{O} 1$ & $\mathrm{C}$ & $\mathrm{O} 2$ \\
\hline
\end{tabular}

Gambar 1 Rancangan Penelitian

Keterangan:
A : Sampel
O1 : Posttest kemampuan awal
$\mathrm{X}$ : Model problem based learning
$\mathrm{C}$ : Model biasa
O2 : Posttest kemampuan akhir

Populasinya dalam penelitian ini adalah semua siswa SMP 1 Mejobo kelas VIII semester II tahun pelajaran 2020/2021. Teknik sampling yang digunakan cluster sampling atau juga cluster random sampling yang merupakan teknik pengambilan sampel yang digunakan bilamana populasi tidak terdiri dari individu-individu, melainkan terdiri dari kelompok-kelompok individu atau claster. Jadi sampel yang digunakan adalah semua siswa kelas VIII-C dan VIII-D.

Tahapan dalam penelitian ini ialah dari studi pendahuluan, uji coba instrumen, pemberian pre test kedua kelas, pelaksanaan pembelajaran kedua kelas, pemberian post test, analisis data. Pengumpulan data yang digunakan meliputi tes kemampuan pemecahan 
masalah. Tes kemampuan pemecahan masalah ditujukan untuk mengetahui bagaimana kemampuan pemecahan masalah siswa sebelum dan sesudah penelitian yang berupa pre-test dan post-test. Sebelum diujikan, instrumen tes tersebut diujikan kepada siswa yang sudah mendapatkan materi tersebut kemudian dianalisis apakah instrumen dapat digunakan atau tidak. Tes tersebut diberikan kepada 13 siswa kelas eksperimen dan 10 siswa kelas kontrol.

Teknik analisis data terdapat dua bagian yaitu analisis data awal dan analisis data akhir. Pada analisis data awal, mengunakan menggunakan hasil nilai PTS kedua kelas. Kemdian diuji menggunakan uji prasyarat dan uji perbedaan rata-rata yang bertujuan bahwa kedua sampel memiliki kesamaan rata-rata kemampuan. Pada analisis akhir, rumusan pertama hasil post test kedua kelas diuji menggunakan uji prasyarat kemudian diuji dengan uji $\mathrm{T}$ dua sampel independen untuk mengetahui perbedaan rata-rata pada kedua kelas. Pada rumusan kedua, hasil pre test dan post test kelas eksperimen diuji prasyarat kemudian diuji dengan uji $\mathrm{T}$ satu sampel dependent untuk mengetahui perbedaan rata-rata pada kelas eksperimen setelah dan sebelum diterapkan model pembelajaran.

\section{HASIL DAN PEMBAHASAN}

Hasil penelitian akan dibahas menjadi beberapa bagian. Berikut adalah hasil yang diperoleh dalam penelitian yang dilakukan, diawali dengan perhitungan statistik uji prasyarat dan diakhiri dengan uji perbedaan rata-rata menggunakan uji-t dua sampel independen dan uji $\mathrm{t}$ dua sampel dependen.

\section{Perbedaan Kemampuan Pemecahan Masalah Kelas Eksperimen Dan Kelas Kontrol}

Sebelum menjawab rumusan masalah penelitian yang diajukan, peneliti melakukan terlebih dahulu asumsi statistik yakni uji normalitas dan uji homogenitas dari hasil posttest kedua kelas. Adapun hasil dari uji normalitas dan homogenitas disajikan pada Tabel 1 dan Tabel 2.

Tabel 1 Uji normalitas kelas ekperimen dan kelas kontrol

\begin{tabular}{lcc}
\hline Kelas & $\begin{array}{c}\text { Banyak } \\
\text { Data }\end{array}$ & $\begin{array}{c}\text { Uji Shapiro } \\
\text { Wilk }\end{array}$ \\
\hline $\begin{array}{l}\text { Kelas } \\
\text { kontrol }\end{array}$ & 6 & 0,888 \\
$\begin{array}{l}\text { Kelas } \\
\text { eksperimen }\end{array}$ & 15 & 0,921 \\
\hline
\end{tabular}

Tabel 2 Uji homogenitas kelas eksperimen dan kelas kontrol

\begin{tabular}{lcc}
\hline \multicolumn{1}{c}{ Kelas } & $\begin{array}{c}\text { Banyak } \\
\text { Data }\end{array}$ & $\begin{array}{c}\text { Uji } \\
\text { Levene's }\end{array}$ \\
\hline $\begin{array}{l}\text { Kelas } \\
\text { kontrol }\end{array}$ & 6 & \\
$\begin{array}{l}\text { Kelas } \\
\text { eksperimen }\end{array}$ & 15 & 0,905 \\
\hline
\end{tabular}

Berdasarkan pengujian SPSS pada Tabel 1 diperoleh nilai signifikan pada kelas kontrol dan kelas eksperimen sebesar 0,2 > 0,05. Maka $\mathrm{H}_{0}$ diterima yang berarti data kelas kontrol dan kelas eksperimen berdistribusi normal. Dengan demikian kedua kelas sampel dinyatakan berdistribusi normal sehingga sampel bisa digunakan untuk penelitian. Berdasarkan pehitungn SPSS pada Tabel 2 diperoleh nilai sig 0,782 > 0,05 . Maka $\mathrm{H}_{0}$ diterima artinya tidak ada perbedaan varian dari beberapa kelompok data dan data bersifat homogen.

Dalam rumusan masalah pertama, ditujukan untuk mengetahui perbedaan 
DOI: https://doi.org/10.24127/ajpm.v10i3.3969

rata-rata kemampuan pemecahan masalah kelas eksperimen dan kelas kontrol. Sehingga dalam penelitian ini mengunakan uji $\mathrm{T}$ dua sampel independen untuk menganalisis data. Adapun hipotesis penelitian yang dilakukan:

$\mathrm{H}_{0}: \mu_{1}=\mu_{2}$, tidak terdapat perbedaan rata-rata kemampuan pemecahan masalah siswa kelas eksperimen sesudah diterapkan model PBL berbantu aplikasi Gagung Duran dan rata-rata kemampuan pemecahan masalah siswa kelas kontrol.
$\mathrm{H}_{1}: \mu_{1} \neq \mu_{2}$, terdapat perbedaan ratarata kemampuan pemecahan masalah siswa kelas eksperimen sesudah diterapkan model PBL berbantu aplikasi Gagung Duran dan rata-rata kemampuan pemecahan masalah siswa kelas kontrol.

Kriteria pengujian yang digunakan sebagai berikut:

- Jika sig $<0,05$, maka $\mathrm{H}_{0}$ ditolak

- Jika sig $\geq 0,05$ maka $\mathrm{H}_{0}$ diterima.

Adapun hasil dari penghitungan mengunakan SPSS pada Tabel 4.

Tabel 3 Uji rata-rata kelas eksperimen dan kelas kontrol

\begin{tabular}{lccc}
\multicolumn{1}{c}{ Kelas } & Banyak Data & $\begin{array}{c}\text { Hasil uji Independent } \\
\text { Sample T-Test }\end{array}$ & Rata-rata \\
\hline Kelas kotrol & 6 & 0,036 & 68,88 \\
Kelas eksperimen & 14 & 79,33 \\
\hline
\end{tabular}

Berdasarkan perhitungan SPSS pada Tabel 3, nilai sig (2tailed) $0,047<0,05$. Maka hipotesis $\mathrm{H}_{0}$ ditolak, yang artinya pada taraf kepercayaan $95 \%$ dapat disimpulkan bahwa $\mu_{1} \neq \mu_{2}$, maka terdapat perbedaan rata-rata kemampuan pemecahan masalah siswa kelas eksperimen sesudah diterapkan model Problem Based Learning berbantuan aplikasi Gagung Duran dan rata-rata kemampuan pemecahan masalah siswa kelas kontrol. Pada hasil perhitungan juga diperoleh baha hasil dari rata-rata kemampuan pemecahan masalah siswa bahwa rata-rata kelas eksperimen lebih tinggi daripada rata-rata kelas kontrol.

Dengan pembelajaran berbasis andoid dalam model Problem Based Learning dapat menjadikan siswa lebih antusias dalam pembelajaran. Selain itu juga dengan penggunaan media pembelajaran dapat menarik minat siswa dalam pembelajaran, sehingga dapat membuat siswa menjadi lebih bersemangat dan menjadikan siswa penasaran dengan apa yang dipelajarinya nanti (Wanabuliandari, 2015). Sehingga siswa dapat membantu siswa untuk mencari informasi untuk menemukan solusi di dalam permasalahan (Fatma \& Partana, 2019). Berdasarkan penelitian yang dilakukan oleh (Hidayanto, Darma, \& Putra, 2020) dengan pembelajaran yang menggunakan media aplikasi yang interaktif dan memuat model pembelajaran dapat membantu siswa dalam mengembangkan kemampuan pemecahan masalah. Selama pelaksanaan pembelajaran berlangsung dengan menggunakan sebuah model dan media pembelajaran yang bersifat individual dapat meningkatkan kemampuan masing-masing siswa dalam memahami materi pembelajaran yang diberikan oleh guru. Menurut (Hidayatsyah, 2021) mengungkapkan dengan pembelajaran berbasis masalah berbantuan media aplikasi dapat meningkatkan kemampuan pemecahan masalah lebih baik daripada pembelajaran secara kovensional. 


\section{Perbedaan Kemampuan Pemecahan Masalah Kelas Eksperimen Sesudah dan Sebelum Diterapkan Perlakuan}

Pada pengajuan rumusan masalah ini, peneliti melakukan uji normalitas dan uji homogenitas terlebih dahulu sebagai uji prasyarat dari hasil post test kedua kelas. Berikut ini merupakan hasil uji Normalitas dan Homogenitas pada Tabel 4 dan Tabel 5.

Tabel 4 Uji normalitas post test kelas eksperimen dan kelas kontrol

\begin{tabular}{lcc}
\hline Nilai & $\begin{array}{c}\text { Banyak } \\
\text { Data }\end{array}$ & $\begin{array}{c}\text { Uji Shapiro } \\
\text { Wilk }\end{array}$ \\
\hline Pretest & 14 & 0,291 \\
Posttest & 14 & 0,738 \\
\hline
\end{tabular}

Tabel 5 Uji homogenitas post test kelas eksperimen dan kelas kontrol

\begin{tabular}{lcc}
\hline \multicolumn{1}{c}{ Kelas } & $\begin{array}{c}\text { Banyak } \\
\text { Data }\end{array}$ & $\begin{array}{c}\text { Uji } \\
\text { Levene's }\end{array}$ \\
\hline Pretest & 14 & 0,054 \\
Posttest & 14 & \\
\hline
\end{tabular}

Berdasarkan pengujian SPSS pada Tabel 4 diperoleh nilai signifikan pada pre-test sebesar $0,118>0,05$. Maka $\mathrm{H}_{0}$ diterima yang berarti data pre-test berdistribusi normal. Sedangkan untuk post-test diperoleh nilai signifikan $0,2>$ 0,05 . Maka $\mathrm{H}_{0}$ diterima yang berarti data post-test berdistribusi normal. Dengan demikian sampel dari kedua kelas dinyatakan berdistribusi normal sehingga sampel bisa digunakan untuk penelitian. Berdasarkan Tabel 5, diperoleh nilai sig 0,544>0,05. Maka $\mathrm{H}_{0}$ diterima artinya tidak ada perbedaan varian dari beberapa kelompok data dan data bersifat homogen.

Dalam rumusan masalah pertama, ditujukan untuk mengetahui perbedaan rata-rata kemampuan pemecahan setelah dan sebelum diterapkan model pembelajaran. Sehingga dalam penelitian mengunakan uji $\mathrm{T}$ dua sampel dependen untuk menganalisis data. Adapun hipotesis penelitian, yaitu:

$\mathrm{H}_{0}: \mu_{1}=\mu_{2}$, tidak terdapat perbedaan kemampuan pemecahan masalah siswa sebelum dan sesudah diterapkan model Problem Based Learning berbantuan aplikasi Gagung Duran.

$\mathrm{H}_{1}: \mu_{1} \neq \mu_{2}$, terdapat perbedaan kemampuan pemecahan masalah siswa sebelum dan sesudah diterapkan model Problem Based Learning berbantuan aplikasi Gagung Duran.

Kriteria pengujian yang digunakan sebagai berikut:

- Jika sig $<0,05$, maka $\mathrm{H}_{0}$ ditolak

- Jika sig $\geq 0,05$ maka $\mathrm{H}_{0}$ diterima.

Adapun hasil dari penghitungan mengunakan SPSS ada pada Tabel 6.

Tabel 6 Uji T pre test dan post test kelas eksperimen

\begin{tabular}{cccc}
\hline Nilai & Banyak Data & Hasil uji Paired Sample T-Test & Rata-rata \\
\hline Pretest & 14 & 0,002 & 66,0000 \\
Posttest & 14 & & 79,3340 \\
\hline
\end{tabular}

Berdasarkan perhitungan SPSS pada Tabel 7 , nilai sig (2tailed) $0,003<0,05$. Maka $\mathrm{H}_{0}$ ditolak, artinya pada taraf kepercayaan 95\% dapat disimpulkan bahwa $\mu_{1} \neq \mu_{2}$, terdapat perbedaan kemampuan pemecahan masalah siswa sebelum dan sesudah diterapkan model Problem Based Learning berbantuan aplikasi Gagung Duran. Pada perhitugan hasil juga diperoleh rata-rata pre test sebesar 66 lebih kecil daripada rata-rata post test yang sebesar 79,33 pada kelas eksperimen. 
DOI: https://doi.org/10.24127/ajpm.v10i3.3969

Perolehan hasil pada Tabel 7 mungkin dikarenakan dengan menggunakan model pembelajaran Problem Based Learning berbantuan aplikasi Gagung Duran dapat menjadikan siswa lebih mandiri dalam proses belajar walaupunhanya diberi arahan oleh gurunya saja. Selain itu pengguanan media android dapat menjadikan siswa bisa memahami materi secara mendalam dengan memberikan permasalahanpermasalahan yang berkaitan dengan kehidupan sehari-hari. Dengan begitu siswa bisa menigkatkan kemampuannya dalam menyelesaikan masalah melalui tahapan-tahapan yang sudah dipelajari di aplikasi android tersebut. Hal ini sesuai dengan penelitian (Hendikawati, Zahid, \& Arifudin, 2019) yang menyatakan dengan penggunaan media pembelajaran berbasis android dapat meningkatkan kemandirian siswa dalam belajar. Menurut (Nugraha \& Setyaningtyas, 2017) mengungkapkan dengan menggunakana model pembelajaran Problem Based Learning berbantuan media aplikasi dapat membuat siswanya menjadi aktif karena dalam pembelajaran siswa dituntut aktif dan disiplin untuk bisa memecakan masalah yang diberikan. (Nikmah, Rahayu, \& Fajrie, 2020) untuk meningkatkan kemampuan pemecahan masalah dapat menggunakan media math mobile learning dan peningkatan kemampuan siswa bisa dilihat berdasarkan rata-rata nilai kelas dan ketuntasana belajar klasikal.

Temuan dalam penelitian ini adalah dengan penggunaan media aplikasi siswa menjadi lebih aktif dan pemahaman siswa dalam konsep masteri bisa dimengerti siswa karena didalam aplikasi tersebut sudah dijelaskan secara rinci mengenai materi garis singgung persekutuan dua lingkaran. Namun dalam pelaksanaan pembelajaran siswa masih kurang dalam memahami materi dengan cepat, karena siswa perlu dibantu dalam pelaksanaan untuk dapat memahaminya. Kelebihan dalam penelitian ini adalah siswa bisa menguasai kemampuan pemecahan masalah siswa dengan baik dan siswa dapat mengerjakan soal-soal non rutin. Sejalan dengan penelitian (Wanabuliandari, 2015) dengan penggunaan media pembelajaran dapat menarik minat siswa dalam pembelajaran, sehingga dapat membuat siswa menjadi lebih bersemangat dan menjadikan siswa penasaran dengan apa yang dipelajarinya nanti. Selain itu menurut (Indriasih, Sumaji, Badjuri, \& Santoso, 2020) penggunaan media digital dapat meningkatkan minat belajar siswa dan mempermudah siswa dalam memahami materi dan meningkatkan motivasi belajar.

Sedangkan menurut (Oktaviana \& Haryadi, 2020) peningkatan kemampuan pemecahan masalah dengan kategori tinggi dapat menggunakan model Problem Based Learning. Menurut (Yerizon, Wahyuni, \& Fauzan, 2021) mengungkapkan untuk meningkatkan kemampuan pemecahan masalah, model Problem Based Learning merupakan salah satu model pembelajaran yang cocok disegala level sekolah. Dampak dari penggunaan media aplikasi sendiri yaitu menjadikan siswa untuk berani untuk mencoba dan terus berusaha untuk menyelesaikan masalah secara runtut.

\section{KESIMPULAN DAN SARAN}

Kemampuan pemecahan masalah siswa antara yang menggunakan Model Problem Based Learning berbantuan aplikasi Gagung Duran lebih baik dibandingkan dengan siswa yang menggunakan pembelajaran konvensional. Selain itu terdapat 
perbedan rata-rata kemampuan pemecahan masalah siswa sebelum dan sesudah diterapkannya Model Problem Based Learning berbantuan aplikasi Gagung Duran. Selain itu dengan pembelajaran menggunakan model Problem Based Learning berbantuan aplikasi Gagung Duran dapat menjadikan siswa memahami konsep dalam sebuah materi, dan juga menjadikan siswanya menjadi berani untuk mecoba dalam sebuah hal. Dengan hasil penelitian seperti ini, bisa menjadikan dasar pengembangan pembelajaran matematika yang akan dilaksanakan seterusnya. Walupun pembelajaran matematika dilaksanakan secara daring, tetapi harus dikembangkan secara konseptual agar dapat memaksimalkan aspek-aspek budaya manusia.

Hasil penelitian akan memperkaya khasanah ilmu pengetahuan, khususnya dalam pengembangan pembelajaran berbasis masalah dalam upaya meningkatkan kemampuan pemecahan masalah disertai peranan media perangkat lunak disesuaikan dengan kebutuhan materi yang diajarkan. Hasil penelitian ini akan menjadi dasar pengembangan inovasi dalam pembelajaran untuk membantu guru dan siswa dalam melakukan pelaksanaan pembelajaran di dalam kelas.

Saran yang untuk penelitian yang sudah terlaksana dan penelitian selanjutnya nanti adalah dalam pelaksanaan pembelajaran lebih terkonsep untuk menjadikan siswanya bisa lebih tertarik lagi untuk mencoba baik dari segi konsep dan isi dari apa yang akan disampaikan atau materi.

\section{DAFTAR PUSTAKA}

Abdurrozak, R., Jayadinata, A. K., \& 'Atun, I. (2016). Pengaruh Model Problem Based Learning
Terhadap Kemampuan Berpikir Kreatif Siswa. Jurnal Pena Ilmiah , 1 (1), 871-880.

Cahyani, H., \& Setyawati, R. W. (2016). Pentingnya Peningkatan Kemampuan Pemecahan Masalah melalui PBL untuk Mempersiapkan Generasi Unggul Menghadapi MEA. Seminar Nasional Matematika $X$ (pp. 151-160). Semarang: Universitas Negeri Semarang.

Fasha, A., Johar, R., \& Ikhsan, M. (2018). Peningkatan Kemampuan Pemecahan Masalah dan Berpikir Kritis Matematis Siswa melalui Pendekatan Metakognitif. Jurnal Didaktik Matematika , 5 (2), 53 64.

Fatma, A. D., \& Partana, C. F. (2019). Pembelajaran berbantu aplikasi android untuk meningkatkan kemampuan Pemecahan Masalah Kimia. Jurnal Inovasi Pendidikan IPA , 5 (2), 229-236.

Hendikawati, P., Zahid, M. Z., \& Arifudin, R. (2019). Keefektivitas Media Pembelajaran Berbasis Android terhadap Kemampuan Pemecahan Masalah dan Kemandirian Belajar. Prisma, 2, 917-927.

Hidayanto, Darma, Y., \& Putra, S. R. (2020). Pengembangan Media Pembelajaran Berbasis Macromedia Flash Bermuatan Problem Posing Terhadap Kemampuan Pemecahan Masalah Matematis. Mosharafa, 9 (2), 323-334.

Hidayatsyah. (2021). Kemampuan Pemecahan Masalah Siswa Menggunakan Model Problem. Jurnal Cendekia , 5 (1), 458470. 
DOI: https://doi.org/10.24127/ajpm.v10i3.3969

Indriasih, A., Sumaji, Badjuri, \& Santoso. (2020). PENgembangan E-Comic Sebagai Media Pembelajaran Untuk Meningkatkan Kecakapan Hidup Anak Usia Dini. Refleksi Edukatika , 10 (2), 154-162.

Kharisma, N. N., Roesminingsih, M. V., \& Suhanadji. (2020). Gambaran Kebutuhan Pembelajaran Daring PKBM Budi Utama Surabaya Pada Masa Pandemi Covid-19. Jurnal Pendidikan Nonformal , 15 (1), 38 - 44.

Nikmah, N., Rahayu, R., \& Fajrie, N. (2020). PEnerapan Media Pembelajaran Math Mobile Learning Untuk Meningkatkan Kemampuan Pemecahan Masalah Siswa Kelas IV. WASIS , 1 (2), 1-8.

Nugraha, A. S., \& Setyaningtyas, E. W. (2017). Peningkatan Hasil Belajar Ipa Dengan Model Problem Based Learning Berbantuan Media Mind Mapping Kelas 5. E-jurnal Mitra Pendidikan , 1 (5), 575586.

Oktaviana, D., \& Haryadi, R. (2020). PEngaruh Model Pembelajaran Problem Based Learning (Pbl) Terhadap Kemampuan Pemecahan Masalah Mahasiswa. Aksioma , 9 (4), 1076-1085.

Puadi, E. F., \& Habibie, M. I. (2018). Implementasi PBL Berbantuan GSP Software Terhadap Peningkatan Kemampuan Pemecahan Masalah Matematik Siswa. Indomath , 1 (1), 19-25.

Putri, R. S., Suryani, M., \& Jufri, L. H. (2019). Pengaruh Penerapan Model Problem Based Learning terhadap Kemampuan Pemecahan Masalah Matematika Siswa. Moshafa , 8 (2), 331-340.
Rerung, N., Sinon, I. L., \& Widayaningsih, S. W. (2017). Penerapan Model Pembelajaran Problem Based Learning (Pbl) Untuk Meningkatkan Hasil Belajar Peserta Didik Sma Pada Materi Usaha Dan Energi. Jurnal Ilmiah Pendidikan Fisika Al-BiRuNi , 6 (1), 47-55.

Sugiyono. (2015). Metodologi Penelitian Pendidikan. Bandung: Alfabeta.

Wanabuliandari, S. (2015). Keefektifan Model Pembelajaran Kooperatif Teams Assisted Individualization Dengan Macromedia Authorware Materi Segi Empat Kelas VII SMPN 3 KUDUS. Refleksi Edukatika , 5 (2), 1-12.

Yerizon, Wahyuni, P., \& Fauzan, A. (2021). Pengaruh Problem Based Learning Terhadap Kemampuan Pemecahan Masalah Matematis Ditinjau Dari Genre Dan Level Sekolah. Aksioma , 10 (1), 105116. 